\title{
CRIME OF GENOCIDE BEFORE THE INTERNATIONAL COURT OF JUSTICE
}

\author{
Prof. dr. sc. Vesna Crnić-Grotic**
}

\author{
UDK: 341.645 .5 .2 \\ https://doi.org/10.30925/zpfsr.40.3.3 \\ Ur.: 20. rujna 2019. \\ Pr.: 11. prosinca 2019. \\ Prethodno priopćenje
}

\begin{abstract}
Summary
When Mr. Raphael Lemkin invented the term genocide in 1944 he was trying to fill the void in the existing list of international crimes because, in his view, none of them was appropriate to address the terrible mass atrocities of World War II. The mass extermination of Jews, Gypsies, Slavs and other groups should have been different from "ordinary" crimes against humanity. His fight led to the adoption of the UN Convention on the Prevention and Punishment of the Crime of Genocide in 1948. Although the Convention was primarily designed to punish individual perpetrators, States parties can also be held responsible for the same crime. The reference in Article IX of the Convention to the jurisdiction of the International Court of Justice clearly shows in that direction. However, the first case appearing before that court was the case of Bosnia v. Serbia in 1993 and the Court made its ruling on the merits in 2007. The following ruling concerned the case of Croatia v. Serbia in 2015. Neither of the final rulings established the responsibility of the respondent state for genocide, although the crime had been established in the case of Bosnia. The article will look into the requirements for the genocide to be established and what was the missing link between the crime and the defendant state.
\end{abstract}

Keywords: Genocide Convention; International Court of Justice; Bosnian genocide case; Croatia; Serbia.

\section{INTRODUCTION}

The crime of genocide is often called the crime of crimes, as the worst crime that can be committed by humans against other humans. Its genesis in legal terms is connected with the atrocities committed in WW2 against the Jews and other groups of people although the "practice" had existed long before that war. ${ }^{1}$ However, the

* Vesna Crnić-Grotić, Ph.D., Full Professor, University of Rijeka, Faculty of Law; vesnacg@ pravri.hr

1 For example, the dispute between Armenia and Turkey about the mass killing of Armenians in 1915-1917 is still on-going. Lately, the dispute was internationalized as other states are taking sides. See the list of States agreeing with Armenia (21) at < http://genocide.am/ 
Convention for the Prevention and Punishment of the Crime of Genocide was adopted after the war. ${ }^{2}$ Legally, that meant that it was not applicable to the crimes committed in WW2 as that would run against the principle of non-retroactivity of criminal law.

It took almost 50 years to have the 1948 Convention applied by international judiciary. Between 1990 and 1998 horrible massive crimes and atrocities were committed in the non-international conflict in Rwanda and the wars in the former Yugoslavia. It was only in the wake of these conflicts that the international criminal tribunals as well as the International Court of Justice (ICJ) and, to a lesser extent, the European Court of Human Rights, had a chance to interpret and apply the Convention. Their judgements reflect their different jurisdictions and their statutes, but their case-law clarified the basic requirements and elements for a crime to be considered "genocide" and to distinguish it from similar concepts of the crimes against humanity and ethnic cleansing.

It will be the task of this paper to look into the present understanding of the crime of genocide as interpreted by these courts with a particular emphasis on the two cases decided by the ICJ dealing with the wars in former Yugoslavia. The first case appearing before that court was the case of Bosnia v. Yugoslavia in 1993. The Court made its ruling on the merits in 2007. The following ruling concerned the case of Croatia v. Serbia in 2015. Neither of the final rulings established the responsibility of the respondent State for genocide, although the crime itself had been established in the case of Bosnia. The article will look into the requirements for the genocide to be established and what was the missing link between the crime and the respondent State.

\section{GENOCIDE AND THE CRIMES AGAINST HUMANITY}

The term genocide was defined as a separate crime by a Polish-Jewish-American lawyer Raphael Lemkin. ${ }^{3}$ In 1944 he wrote about "a crime without a name" consisting of "the destruction of whole populations - of national, racial and religious groups both biologically and culturally". ${ }^{5}$ The planned and systematic extermination of the whole nations had to be treated differently due to its horrific nature so Lemkin coined a new name from the Greek genos, meaning race or tribe, and the termination "-cide", from the Latin caedere, to kill. The core of his definition related to "a conspiracy to

article/recognition_of_the_armenian_genocide.html> (visited 17.09.2019). In 2015 the Grand Chamber of the European Court of Human Rights (ECtHR) ruled that it was against Art. 10 (freedom of expression) of the ECHR to punish the applicant for denying the genocide in Armenia. Perinçek v. Switzerland, ECtHR GC 2015, para. 280.

2 The Convention was adopted unanimously by the UN General Assembly, 9 Dec. 1948. United Nations, Treaty Series, vol. 78, p. 277.

3 Lemkin, R., Axis Rule in Occupied Europe: Laws of Occupation, Analysis of Government, Proposals for Redress, Washington: Carnegie Endowment for World Peace, 1944. See about Lemkin's legacy in Sands, Phillipe, East West Street: On the Origins of Genocide and Crimes against Humanity, Weidenfeld \& Nicolson, 2016.

4 Lemkin attributes this phrase to Winston Churchill. Raphael Lemkin, 'Genocide', 15 (2) American Scholar, 227 (1946), p. 227. Available at: < http://www.preventgenocide.org/lemkin/ americanscholar1946.htm> (visited 17.09.2019).

5 ibid. 
exterminate national, religious or racial groups" reflecting the Holocaust committed against Jews and other groups in WW2. ${ }^{6}$

By that time it was already too late to have this crime included in the Nuremberg trial to the Nazi leading criminals. ${ }^{7}$ The trial was based on the London Charter and the Statute of the International Military Tribunal from 1945. It provided three categories of crimes: crimes against the peace, war crimes and crimes against humanity, which included murder, enslavement or deportation of civilians or persecution on political, religious or racial grounds. As described in the London Charter and based in international customary law, the crimes against humanity come rather close to the crime of genocide, so much so, that genocide is considered to be part of the crimes against humanity. ${ }^{8}$ However, there were several important 'deficiencies' in the crimes against humanity that were not able to cover all the aspects of genocide. First of all, these crimes were confined to atrocities committed in association with an aggressive war and the crimes committed during peace-time were not included. The Nazi regime, however, began with atrocities before the war began. ${ }^{9}$ Furthermore, crimes against nationals were also excluded, while the first victims of the Holocaust were the German nationals. The definition of the crimes against humanities protected civilian population as such regardless of their national, ethnic or religious affiliation. Finally, the crimes against humanity were covered by national jurisdiction and it was necessary to make it subject to international jurisdiction. ${ }^{10}$

Lemkin advocated and even strongly lobbied for the adoption of a new international convention that will have covered genocide as a separate crime, different from the hitherto existing crimes against humanity with all their limitations. The United Nations General Assembly was open to suggestion based on the 1946 GA

6 ibid.

7 The International Criminal Tribunal for Rwanda (ICTR) pointed out in Kambanda: "the crimes prosecuted [at Nuremberg] ... were very much constitutive of genocide, but could not be defined as such because the crime of genocide was not defined until later." Prosecutor v. Kambanda, ICTR 97-23-S, Judgment and Sentence, 4 September 1988, para. 16.

8 The International Criminal Tribunal for the former Yugoslavia (ICTY) concluded that genocide was a crime against humanity and that it belonged to a 'genus' that included the crime against humanity of persecution. Prosecutor v. Sikirica et al., (Case No. IT-95-8-I), Judgment on Defence Motions to Acquit, 3 September 2001, para. 58, a. See: Daillier, P., Pellet, A., Quoc Dinh, N., Droit International Public, $7^{\text {th }}$ ed., Paris, L.G.D.J., 2002, p. 715.

9 Schabas claims that since then the law concerning crimes against humanity has evolved substantially: "That crimes against humanity may be committed in time of peace as well as war has been recognized in the case law of the ad hoc international tribunals, and codified in the Rome Statute." Schabas, W., Genocide in International Law: The Crime of Crimes, $2^{\text {nd }}$ ed., Cambridge, Cambridge University Press, 2009, p. 14.

10 The existing law at the time was interpreted as preventing interfering in 'domestic affairs' whatever their nature. (The concept still exists and is known as domain réservé although much narrower). Allied Powers were looking for the way to include the atrocities committed against Germans under the charges in Nuremberg so they connected them to the aggressive war: "They were a part of the preparation for war or for the conduct of the war in so far as they occurred inside of Germany and that makes them our concern." Minutes of Conference Session of 23 July 1945, available at < http://avalon.law.yale.edu/imt/jack44.asp > (visited 17.09.2019). 
Resolution 96/I on the crime of genocide. ${ }^{11}$ The initiative was finalized at the Third GA Session in 1948. The Convention for the Prevention and Punishment of the Crime of Genocide (henceforth: the Convention) was adopted unanimously at the same session as the Universal Declaration of Human Rights, another fundamental instrument for the protection of human rights. ${ }^{12}$ They both marked the beginning of an era in which the protection and promotion of human rights will be an object of international cooperation and universal implementation.

The Convention entered into force in 1951 after the first twenty instruments of ratification were deposited and in 2019 it has 152 States Parties out of 193 UN Member States. ${ }^{13}$ Its Article IX provides for the jurisdiction of the International Court of Justice (ICJ) for disputes between the States Parties "relating to the interpretation, application or fulfilment of the present Convention, including those relating to the responsibility of a State for genocide or for any of the other acts enumerated in article III ... at the request of any of the parties to the dispute." This provision will be the legal foundation for the disputes that were brought before the ICJ in 1990ies. ${ }^{14}$ For the first time in its history they gave the ICJ the opportunity to give its interpretation of the Convention and to connect it to the rules on State responsibility.

However, before the inter-State genocide cases, the ICJ had had a chance to look into the Convention but from another point of view. Namely, in 1951 the UN GA asked the Court to give an advisory opinion regarding the reservations to the Genocide Convention. ${ }^{15}$ In it opinion the ICJ associated GA Resolution 96(I) with the Convention and concluded "that the principles underlying the Convention are principles which are recognized by civilized nations as binding on States, even without any conventional obligation" thus recognizing the universal nature of its rules. ${ }^{16}$

Today there is no doubt that there is an international law rule prohibiting genocide and that it is an imperative norm (jus cogens) of international law. ${ }^{17}$ Furthermore, the

11 The text of the resolution is available at: <http://www.un.org/documents/ga/res/1/ares $1 . \mathrm{htm}>$ (visited 17.09.2019).

12 Universal Declaration of Human Rights was adopted on 10 December 1948. GA Res. 217A (III), UN Doc A/810 at 71 (1948).

13 UN Treaty Collection, available at: $<$ https://treaties.un.org/>. According to Art. 14 the Convention had a limited duration of 10 years that was supposed to be extended thereafter for successive periods of five years. So far, neither party has renounced the Convention.

14 Degan claims that this is the only multilateral treaty which entitles its States-parties to unilaterally bring claims against any other State-party before the ICJ. Degan, V. Đ., Zločin genocida pred Međunarodnim sudom u Haagu, Zbornik radova Pravnog fakulteta u Splitu, 53, 2/2016, p. 334.

15 The request was provoked by the fact that some States, including the Soviet Union, made a reservation to Art. IX. The question was raised by some other States (signatory and contracting States) whether they were entitled to do so and even whether they could be considered parties to the Convention.

16 Reservations to the Convention on the Prevention and Punishment of the Crime of Genocide (Advisory Opinion), [1951] I.C.J. Reports 16, p. 23.

17 The concept of jus cogens was codified in the Vienna Convention on the Law of Treaties, Art. 50. The UN International Law Commission illustrated the concept with, among others, the use of force, piracy and genocide. Daillier and Pellet, op.cit., p. 205. 
norm has erga omnes scope. ${ }^{18}$ This has been broadly accepted by the writers and the practitioners not just of international law, but also at the national level. ${ }^{19}$ The ICJ has confirmed that the prohibition of genocide is a rule of the customary international law. ${ }^{20}$ Moreover, the ICJ confirmed that the prohibition of genocide is ,,assuredly" a peremptory norm (jus cogens) of international law. ${ }^{21}$

In further development of international criminal law the Security Council of the UN established two international criminal courts: the International Criminal Tribunal for the former Yugoslavia (ICTY) and the International Criminal Tribunal for Rwanda (ICTR). Their respective statutes include the crime of genocide as one of the punishable acts. ${ }^{22}$ Consequently, these tribunals were in position to apply and interpret the elements of the crime of genocide in relation to individual criminal responsibility. The ICJ recognized the value of their work in establishing facts although the ICJ has not always accepted their legal views. ${ }^{23}$ In both the Bosnian and the Croatian case the ICJ accepted "as highly persuasive relevant findings of fact" by the ICTY and claimed that it would attach "the utmost importance to the factual and legal findings made by the ICTY in ruling on the criminal liability of the accused before it" including the Tribunal's findings about the existence of the required intent. ${ }^{24}$

The International Criminal Court (ICC) established in 2002 by the Rome Statute as a permanent criminal court also provides for the crime of genocide as one of the

18 The concept of erga omnes obligations was confirmed by the ICJ in the Barcelona Traction case (Barcelona Traction, Light and Power Company, Limited, Judgment, I.C.J. Reports, 1970, p. $3,32)$. Shaw explains the difference between these two concepts in the following way: "While there may be significant overlap between these two in terms of the content of rules to which they relate, there is a difference in nature. The former concept concerns the scope of application of the relevant rule, that is the extent to which states as a generality may be subject to the rule in question and may be seen as having a legal interest in the matter. It has, therefore, primarily a procedural focus. Rules of jus cogens, on the other hand, are substantive rules recognised to be of a higher status as such." Shaw, M., International Law, $6^{\text {th }}$ ed., Cambridge, Cambridge University Press 2008, p. 124.

19 See Jorgic v. Germany, ECtHR 2007. The applicant was sentenced by German courts for genocide committed in Bosnia (Doboj).

20 For example in Application of the Convention on the Prevention and Punishment of the Crime of Genocide (Croatia v. Serbia), Judgment, I.C.J. Reports 2015, p. 3., (henceforth: Croatia 2015), para. 105.

21 Armed Activities on the Territory of the Congo (New Application: 2002) (Democratic Republic of the Congo v. Rwanda), Jurisdiction and Admissibility, Judgment, I.C.J. Reports 2006, p. 6, para. 64, p. 32 .

22 The tribunals were established by the UN SC resolutions: UN Doc. S/RES/827 (1993), Statute of the International Criminal Tribunal for the Former Yugoslavia; UN Doc. S/RES/955 (1994), Statute of the International Criminal Tribunal for Rwanda.

23 See critical observations by Sa'Couto, S., Reflections on the Judgment of the International Court of Justice in Bosnia's Genocide Case against Serbia and Montenegro, Human Rights Brief, 15, 2/2007, pp. 2-6.

24 Application of the Convention on the Prevention and Punishment of the Crime of Genocide (Bosnia and Herzegovina v. Serbia and Montenegro), Judgment, I.C.J. Reports 2007, p. 43, paras. 223 and 403 (henceforth: Bosnia 2007). The same approach was taken in the Croatian case. Croatia 2015, para. 182. 
punishable acts. ${ }^{25}$ However, more than 15 years on this court has not developed any relevant practice concerning genocide. ${ }^{26}$

\section{GENOCIDE CASES BEFORE THE INTERNATIONAL COURT OF JUSTICE}

As said before, the ICJ has been in position to interpret the 1948 Convention in connection with the wars in the former Yugoslavia. The break-up of Yugoslavia was bloody and cruel. The regime of Slobodan Milošević in Belgrade incited wars in Croatia, Bosnia and Hercegovina and finally in Kosovo that resulted in barbaric atrocities and violence. Two States, Bosnia and Hercegovina in 1993 and Croatia in 1999, decided to engage Art. IX of the Convention. They brought cases against Serbia to the ICJ in The Hague claiming that the atrocities committed by the Yugoslav People's Army and the Serbian forces amounted to genocide and that Serbia was internationally responsible. ${ }^{27}$ Serbia filed counter-claims in both cases but retracted the one against Bosnia and Hercegovina. Before the decision was made on the merits, in both cases the Court had to resolve the issue of its jurisdiction because Serbia objected to it. Consequently, the Court ruled that it had jurisdiction to deal with the disputes on the basis of Article IX of the Genocide Convention..$^{28}$

During the same period and following the NATO bombing of the FRY, that State brought claims against ten NATO member States invoking the Genocide Convention's Art. IX. However, all the cases were dismissed by the Court in the preliminary phase concluding that it lacked jurisdiction in all of these cases. ${ }^{29}$

It would not be possible in this article to describe in details the factual and juridical conclusions of the Court in the genocide cases so the emphasis will be put on the ICJ holdings in the interpretation of Art. II of the Convention relating to the definition of the elements of the crime of genocide. The views held by the ICJ clarified

25 Rome Statute of the International Criminal Court, 2187 U.N.T.S. 90, signed in 1998, entered into force 1 July 2002 .

26 So far, there has been only one defendant charged with the crime of genocide, Omar Al-Bashir. However, he is still at large so the case is in pre-trial phase. International Criminal Court, $<$ https://www.icc-cpi.int/darfur/albashir $>$ (visited 17.09.2019).

27 Originally, claims were made against the Federal Republic of Yugoslavia (Serbia and Montenegro). The FRY tried to claim continuity with the former State SFRY by a declaration adopted on 27 April 1992. However, in 2006 that State devolved to Serbia and Montenegro. The Court accepted that Serbia took the respondent's position in both cases.

28 Application of the Convention on the Prevention and Punishment of the Crime of Genocide (Bosnia and Herzegovina v. Yugoslavia), Preliminary Objections, Judgment of 11 July 1996, I.C.J. Reports 1996, p. 595 (henceforth: Bosnia 1996). Application of the Convention on the Prevention and Punishment of the Crime of Genocide (Croatia v. Serbia), Preliminary Objections, Judgment, I.C.J. Reports 2008, p. 412 (henceforth: Croatia 2008).

29 The cases are called Case concerning the Legality of the Use of Force, decided in 1999 and 2004 respectively. In 2002, the Democratic Republic of Congo charged Rwanda with genocide. The case was dismissed in 2006 based on Rwanda's reservation to Art. IX of the Convention. Armed Activities on the Territory of the Congo (New Application: 2002) (Democratic Republic of the Congo v. Rwanda), Jurisdiction and Admissibility, Judgment, I.C.J. Reports 2006, p. 6. 
much of the insecurity and variety of approaches to this issue and consolidated many aspects of this crime. It is only normal that the Court did it in the context of the contemporary developing international criminal and humanitarian law. Nevertheless, critics may also ask whether the ICJ failed fully to use the opportunity to help prevent and punish the crime of genocide as well as to make States responsible for those under their wing who commit the crime.

\subsection{Definition of Genocide}

The ICJ decided that the Convention is the sole basis of its jurisdiction and the applicable law. It would, however, also apply other applicable rules of international law, such as the rules on interpretation of treaties or those relating to the responsibility of States. ${ }^{30}$ In other words, it would not look beyond the Convention for establishing whether the crime of genocide was committed. Consequently, if the crime was not committed, the Court would not look into any other question.

Art. II of the Convention defines the crime of genocide as: "any of the following acts committed with intent to destroy, in whole or in part, a national, ethnical, racial or religious group, as such:

(a) Killing members of the group;

(b) Causing serious bodily or mental harm to members of the group;

(c) Deliberately inflicting on the group conditions of life calculated to bring about its physical destruction in whole or in part;

(d) Imposing measures intended to prevent births within the group;

(e) Forcibly transferring children of the group to another group."

Accordingly, there are two elements of the crime: a) Actus reus as the physical element and b) Mens rea as the mental element of the act. The mens rea is necessary in criminal law as the perpetrator, in order to be held responsible, has to have the intent to commit the acts - willingly or inadvertently or with negligence. However, the mens rea in this instance includes dolus specialis - a special intent that the ICJ ultimately held to be the most important part of the definition. It has to be established in order to distinguish genocide from other serious crimes committed during the conflicts. ${ }^{31}$ The Court emphasised that these elements are linked and that the "determination of actus reus can require an enquiry into intent". 32

In order to determine the mental element, the Court had to establish the meaning of "destruction of a group". The group in this context must be distinguishable from other groups but it does not mean the group in its totality since the Convention provides

30 Croatia 2015, para. 124-125.

31 Shaw concludes: "[P] $]$ erhaps the distinctive feature of the crime is the importance of establishing the specific intent to destroy the group in question in whole or in part, for genocide is more than the act of killing. This was emphasised by the ICTY in the Jelisic case, which noted that 'it is in fact the mens rea [i.e. the intention as distinct from the actual act] which gives genocide its speciality and distinguishes it from an ordinary crime and other crimes against international humanitarian law'." Shaw, M., op. cit., p. 431.

32 Croatia 2015, para. 130. 
for the destruction of the group "in whole or in part". In Bosnia the Court established that "in part" has to relate to a substantial part of the group. ${ }^{33}$ Furthermore, the size of the group is determined with respect to the geographical area of the perpetrator's activity and control such as a region of a country or even a municipality. ${ }^{34}$ The Court relied on the Krstic judgment of the ICTY that even the prominence of the destroyed group may be relevant "if a specific part of the group is emblematic of the overall group" ${ }^{35}$ These criteria were used by the Court both in the Bosnian and the Croatian case.

In the case of Bosnia the Court did not accept "non-Serbs" to be considered as a group within the meaning of Art. II although the Serbian forces conducted violence against Muslims, Croats and members of other groups without much distinction..$^{36} \mathrm{On}$ the other hand, Muslim men in the Srebrenica region could be considered as a group that was the object of destruction. ${ }^{37}$ In Croatia, the Croats were a majority population in Croatia and they could be taken as a protected group, but they were not all targeted by the considered acts. The part of the population that lived in the areas under attack, however, was accepted by the Court as forming a 'substantial part' of the protected group. ${ }^{38}$

The core of the crime of genocide is the destruction of the group. The Court insists that the destruction has to be physical or biological and that all acts enumerated in Art. II have to have that object or intent. ${ }^{39}$ According to the Court "the intent to destroy a national, ethnic, racial or religious group as such is specific to genocide and distinguishes it from other related criminal acts such as crimes against humanity and persecution". ${ }^{40}$ This intent reflects dolus specialis. The killings have to be deliberate; the torture, including rape, has to be serious and contributing to the destruction of the group as have to be the conditions of life that the group was put in. The overall number of victims has to, therefore, reflect that intent and it has to be substantial. ${ }^{41}$

33 Bosnia 2007, p. 126, para. 198.

34 ibid, para. 199.

35 The ICTY concluded that "the intent to destroy a group, even if only in part, means seeking to destroy a distinct part of the group as opposed to an accumulation of isolated individuals within it." Krstić case, Judgment of 19 April 2004, para. 12.

36 Bosnia 2007, para. 196. In comparison, the ICTY often uses this expression.

37 Bosnia 2007, para. 296.

38 This was not disputed by Serbia. Croatia 2015, paras. 205, 406.

39 The Court did not accept "cultural genocide" although it took into consideration acts of destruction of cultural monuments and institutions as part of efforts to destroy the group: "[The Court] endorses the observation made in the Krstić case that 'where there is physical or biological destruction there are often simultaneous attacks on the cultural and religious property and symbols of the targeted group as well, attacks which may legitimately be considered as evidence of an intent to physically destroy the group."” Bosnia 2007, para. 344. Similar reasoning found in Croatia 2015, para. 387.

40 Bosnia 2007, pp. 121-122, paras. 187-188.

41 In the Croatian case the Court opined that the number of 12.500 deaths claimed by Croatia "is small in relation to the size of the targeted part of the group" (1.7 to 1.8 millions), Croatia 2015, para. 437. With respect to the counter-claim the Court emphasized that "not all of the acts alleged by Serbia as constituting the physical element of genocide have been factually proved. Those which have been proved, in particular the killing of civilians and the ill-treatment of 
As for the physical element of the crime, it consists of the acts enumerated in Art. II of the Convention. In the cases brought by Bosnia and Croatia the parties showed evidence of mass killings, tortures, rapes, mutilations, even death camps. Much of the evidence was taken from the case law of the ICTY that the ICJ, as was shown above, accepted "as highly persuasive". ${ }^{42}$ Based on this and other evidence, the Court did not have many difficulties in concluding that actus reus had in most cases been established, especially with respect to paragraphs a) and b) of Art. II. ${ }^{43}$ In addition, the Court established that concentration or death camps in Bosnia were the places where terrible conditions were inflicted upon detainees. ${ }^{44}$

However, the established actus reus does not amount to genocide unless committed with the special intent or dolus specialis which takes it over the threshold from crime against humanity to the "crime of crimes". In the Bosnian genocide case the Court made very explicit interpretation of that requirement:

" 187 . It is not enough that the members of the group are targeted because they belong to that group, that is because the perpetrator has a discriminatory intent. Something more is required. The acts listed in Article II must be done with intent to destroy the group as such in whole or in part. The words 'as such' emphasize that intent to destroy the protected group."

The crime of "ethnic cleansing" is often overlapping with genocide due to the similarities between their executions. ${ }^{45}$ It is fair to say that the actus reus is the same since in both cases it includes extreme violence against the protected population. ${ }^{46}$ The Court, nevertheless, rejected to consider ethnic cleansing as genocide despite the fact

defenceless individuals, were not committed on a scale such that they could only point to the existence of a genocidal intent”. Ibid, para. 512.

42 The Serbian counter-claim against Croatia relied mostly on the Trial Chamber verdict against Croatian generals Gotovina and Markač. However, when the Appeals Chamber quashed the conviction and acquitted the generals the ICJ took only the parts that were not "upset" by the Appeals Chamber judgment. The Court held that: "the Court cannot treat the findings and determinations of the Trial Chamber as being on an equal footing with those of the Appeals Chamber. In cases of disagreement, it is bound to accord greater weight to what the Appeals Chamber Judgment says, while ultimately retaining the power to decide the issues before it on the facts and the law". Croatia 2015, para. 471.

43 It is not necessary to commit all the acts enumerated in Art. II. "Report of the International Law Commission on the Work of Its Forty-Eighth Session, 6 May-26 July 1996," UN Doc. A/51/10, Commentary on Article 17, para. 18.

44 Bosnia 2007, para. 354. However, the Court did not accept that these acts were perpetrated with the necessary dolus specialis.

45 According to the Commission of Experts established by the UN SC in 1992 (Res. 780) "ethnic cleansing" is a "relatively new" expression (Interim Report of 10 February 1993, UN Doc. S/25274:).The Rome Statute of the ICC recognizes the "deportation or forcible transfer of population" as a crime against humanity in Art. 7(2) although it does not use the term "ethnic cleansing" in its provisions. See: Singleterry, D., "Ethnic Cleansing" and Genocidal Intent: A Failure of Judicial Interpretation?, Genocide Studies and Prevention: An International Journal, 5, 1/2010. Available at: <http://scholarcommons.usf.edu/gsp/vol5/iss1/4> (visited 17.09.2019).

46 "The term 'ethnic cleansing' is used as a euphemism for genocide despite it having no legal status.” Blum, R. et al., 'Ethnic Cleansing' Bleaches the Atrocities of Genocide, European Journal of Public Health, 18, 2/2007, p. 204. 
that the former may amount to the latter. Whether genocide happened will depend "on the presence or absence of acts listed in Article II of the Genocide Convention, and of the intent to destroy the group as such. In fact, in the context of the Convention, the term "ethnic cleansing" has no legal significance of its own." ${ }^{47}$ It may, however, "be significant as indicative of the presence of a specific intent (dolus specialis) inspiring those acts". ${ }^{4}$

How does one establish whether the crimes were perpetrated with the special intent to destroy a national, ethnic or religious group? The difficulty of obtaining explicit genocidal plans seems to have been foreseen by the drafters of the Convention. They rejected proposals to include "issuing instructions or orders and distributing tasks with a view to committing genocide" among the crimes listed in Art. II. ${ }^{49}$ Obviously, a political proclamation by an official State body would not be easily found. ${ }^{50}$

In the Bosnian case the Court rejected Applicant's claim that the Decision on Strategic Goals issued on 12 May 1992 by Momčilo Krajišnik as the President of the National Assembly of the Republika Srpska, published in the Official Gazette of the Republika Srpska or some subsequent statements made by Karadžić were establishing the specific intent to commit genocide. Although they spoke of the intent to create an ethnically clean Serbian State, the Court was not convinced that this goal could only be achieved through genocide. In the Croatian case the Court did not accept that a memorandum issued by the Serbian Academy of Science is contemplating the future genocide for the purpose of creating the Greater Serbia. The document has, in the Court's view, no official standing and "certainly does not contemplate the destruction of the Croats" ${ }^{51}$ In the case of the Serbian counter-claim against Croatia, the Court rejected claims by Serbia that the so-called Brioni Transcript of the meeting of Croatia's top military leaders before the military operation "Storm" would represent a genocidal plan. Instead, the Court concluded that it is "far from demonstrating an intention on the part of the Croatian leaders physically to destroy the group of Croatian Serbs, or the substantial part of that group constituted by the Serbs living in Krajina." 52

In absence of a State plan the Court looked for the special intent through "the pattern of behaviour" or "the pattern of conduct". In addition, it "may be inferred from the individual conduct of perpetrators of the acts contemplated in Article II of the Convention". ${ }^{53}$ In its 2007 Judgment, the Court held that:

47 Bosnia 2007, para. 190.

48 loc. cit.

49 UN Doc. A/C.6/215 Rev. 1. The origin of the term and its connection to genocide is discussed in a contemporary article by Petrović, D., Ethnic Cleansing - An Attempt at Methodology, European Journal of International Law, 5, 3/1994, p. 342.

50 Even the final protocol of the Wannsee Conference held in 1942 never explicitly mentioned extermination of the Jews although it was the bases of the Holocaust. Wannsee Conference, $<$ https://www.britannica.com/event/Wannsee-Conference> (visited 17.09.2019).

51 Croatia 2015, para. 422. The Court also rejected statements made by Vojislav Šešelj and other political figures as un-official.

52 Croatia 2015, para. 504. The same conclusion was made by the Trial and the Appeals Chamber in the Gotovina case.

53 In Blagojević the ICTY Trial Chamber concluded that it is "not sufficient that the perpetrator 
"The dolus specialis, the specific intent to destroy the group in whole or in part, has to be convincingly shown by reference to particular circumstances, unless a general plan to that end can be convincingly demonstrated to exist; and for a pattern of conduct to be accepted as evidence of its existence, it would have to be such that it could only point to the existence of such intent". ${ }^{54}$

Moreover, "for a pattern of conduct, that is to say, a consistent series of acts carried out over a specific period of time, to be accepted as evidence of genocidal intent, it would have to be such that it could only point to the existence of such intent, that is to say, that it can only reasonably be understood as reflecting that intent". ${ }^{55}$

Looking at the established actus reus in the cases before it, the Court recognized the necessary intent only in the massacre in Srebrenica when about 8.000 Muslim men had been killed between 13 and 19 of July $1995 .{ }^{.6}$ In reaching this conclusion the Court relied heavily on the ICTY judgments in the Krstić and the Blagojević and Jokić cases, accepting their findings that the Serbian forces at one point changed their military target from "reducing the enclave to the urban area" to "taking over Srebrenica town and the enclave as a whole." Moreover:

"[A]11 these acts constituted a single operation executed with the intent to destroy the Bosnian Muslim population of Srebrenica. The Trial Chamber finds that the Bosnian Serb forces not only knew that the combination of the killings of men with the forcible transfer of women, children and elderly, would inevitably result in the physical disappearance of the Bosnian Muslim population of Srebrenica, but clearly intended through these acts to physically destroy this group. ${ }^{" 57}$

As for other instances that Bosnia claimed were genocide the Court agreed that in many places horrific crimes were committed against the non-Serb population and the pattern of conduct was discernible. Nevertheless, none of them amounted to genocide but was consistent with crimes against humanities, crime of persecution, killing, torture, rape, ethnic cleansing. ${ }^{58}$

In the Croatian case the Court accepted that there was a "pattern of conduct ... in widespread attacks by the JNA and Serb forces on localities with Croat populations in various regions of Croatia, according to a generally similar modus operandi." ${ }^{59}$ It consisted of a joint attack and occupation by the JNA and Serb forces of the

simply knew that the underlying crime would inevitably or likely result in destruction of the group. The destruction, in whole or in part, must be the aim of the underlying crime(s)." Blagojević, IT-02-60-T, Judgment, 17 January 2005, para. 656.

Bosnia 2007, pp. 196-197, para. 373. Croatia 2015, para.145

55 Croatia 2015, para. 510.

56 Bosnia 2007, para. 295-297.

57 Blagojević, IT-02-60-T, Judgment, 17 January 2005, para. 674, 677.

58 "...the Applicant has not established that any of the widespread and serious atrocities, complained of as constituting violations of Article II, paragraphs (a) to (e), of the Genocide Convention, were accompanied by the necessary specific intent (dolus specialis) on the part of the perpetrators. It also finds that the Applicant has not established the existence of that intent on the part of the Respondent, either on the basis of a concerted plan, or on the basis that the events reviewed above reveal a consistent pattern of conduct which could only point to the existence of such intent." Bosnia 2007, para. 376.

59 Croatia 2015, para. 416 
localities. They would then create a climate of fear and coercion, by killing people and committing other violent acts against the population and the occupation would end with the forced expulsion of the Croat population. ${ }^{60}$ Nevertheless, the Court insisted that the genocidal intent had to be the only possible reasonable conclusion of the pattern of conduct which the Court could not reach in this case. In its view, there could be other explanations for such conduct, like the ethnic cleansing that the Court refused to equate with genocide or the punishment of the enemy, as the Court concluded in one of the most prominent cases claimed by Croatia, that of the massacre of Vukovar. ${ }^{61}$ In the case of counter-claim of Serbia against Croatia, the Court could not establish the pattern of conduct. Despite the established actus reus in some instances, the Court concluded that "Serbia's 'pattern of conduct' argument cannot succeed. The Court cannot see in the pattern of conduct on the part of the Croatian authorities immediately before, during and after Operation "Storm" a series of acts which could only reasonably be understood as reflecting the intention, on the part of those authorities, physically to destroy, in whole or in part, the group of Serbs living in Croatia." The scale of the crimes committed did not point "to the existence of a genocidal intent". ${ }^{62}$

In conclusion, the ICJ accepted that the crime of genocide was only committed in Srebrenica since all the elements of the crime of genocide were established. Genocide was committed by the VRS - the Army of the Republika Srpska, a paramilitary force of the Bosnian Serbs. The next question to be answered by the Court was whether the Republic of Serbia was responsible for the acts committed by the VRS.

The Croatian claim, on the other hand, was rejected as was the Serbian counterclaim because no genocide was established by the Court. ${ }^{63}$

\section{STATE RESPONSIBILITY FOR GENOCIDE}

The established genocide ergo was perpetrated by a non-state actor - the paramilitary forces belonging to the self-proclaimed State of the Republika Srpska. However, Bosnia claimed that the responsibility lies with the State of FRY/Serbia that "directly, or through the use of its surrogates" breached the 1948 Convention. In order to establish Serbia's responsibility the Court turned to the rules on State responsibility under customary international law. It had to decide whether the acts were committed by persons or organs whose conduct is attributable, specifically in the case of the events at Srebrenica, to the Respondent. ${ }^{64}$

60 ibid., para. 415 .

61 ibid., para. 430. The Court relied on the findings of the ICTY and the fact that no charges were made for genocide in Ovčara mass killings after the fall of Vukovar. It also gave weight to the fact that a number of prisoners and Croatian civilians had been "released". In fact, many had been taken to prison camps in Serbia and exposed to killings and further violence.

62 Croatia 2015, para. 511-512.

63 The counter-claim was rejected unanimously while the Croatian claim was rejected with two dissenting opinions by judges Cançado Trindade and Vukas (ad hoc judge).

64 At the outset, the Court rejected the alleged admission by Serbia made by a declaration by the Council of Ministers in June 2005. 
The Court confirmed that States can be responsible for the crime of genocide, not just for failing to prevent it but also for perpetrating it:

"It would be paradoxical if States were thus under an obligation to prevent, so far as within their power, commission of genocide by persons over whom they have a certain influence, but were not forbidden to commit such acts through their own organs, or persons over whom they have such firm control that their conduct is attributable to the State concerned under international law. In short, the obligation to prevent genocide necessarily implies the prohibition of the commission of genocide." ${ }^{65}$

States can commit international crimes through the actions of their organs or persons or groups whose acts are attributable to them but, said the ICJ, the evidence had to be "at a high level of certainty appropriate to the seriousness of the allegation."

The rules on attribution are codified by the ILC Draft Articles on State Responsibility (henceforth: Draft Articles) as adopted by the UN GA resolution in $2001 .{ }^{67}$ Accordingly, States are first and foremost responsible for the acts or omissions by their proper organs.

In this particular case it was necessary to establish whether the (then) FRY or its military, being indisputably an organ of the FRY, took part in the Srebrenica massacre. The Court limited the inspection to a very narrow time-window in July 1995 when the genocide had taken place. It established that the FRY army participated in military operations in Bosnia and Herzegovina in the years prior to the events at Srebrenica but refused to accept as proved "that there was any such participation in relation to the massacres committed at Srebrenica". ${ }^{68}$ The arguments that the VRS staff, (possibly) including General Mladić as the commander in chief, remained on the payroll of the FRY the ICJ also rejected. It held that this reason alone is not sufficient to consider the VRS or General Mladić Serbia's State organs as used in customary international law and in Art. 4 of the Draft Articles. ${ }^{69}$ The Court basically assumed that " $[\mathrm{t}]$ hose officers were appointed to their commands by the President of the Republika Srpska, and were subordinated to the political leadership of the Republika Srpska. In the absence of evidence to the contrary, those officers must be taken to have received their orders from the Republika Srpska or the VRS, not from the FRY". ${ }^{70}$

A similar argument - based on assumptions - seems to have been used with respect to the various military units taking part in genocide. The ICJ established that

65 Bosnia 2007, para. 166.

66 ibid., para. 210 The critics noted, however, that the ICJ accepted the withholding of evidence by Serbia with limited reference to Art. 49 of its Statute. Bosnia requested the Court to ask Serbia to provide clean copies (without black marker editing) of documents of the Supreme Defence Council of Serbia but the Court denied the request claiming that "the Applicant has extensive documentation and other evidence available to it, especially from the readily accessible ICTY records." Ibid, para. 206. For critical remarks see: Bosnia 2007, Dissenting Opinion of VicePresident Al-Khasawneh, para. 35.

67 The UN General Assembly took note of the Draft Articles in Resolution A/RES/56/83 of 12 December 2001.

68 Bosnia 2007, para. 386.

69 Draft Articles, Art. 4.2: „An organ includes any person or entity which has that status in accordance with the internal law of the State."

70 Bosnia 2007, para. 388. 
the "Scorpions" could have been a State organ of the FRY in 1991 but lacked evidence that they were still holding the same position in mid-1995 in Srebrenica. ${ }^{71}$ In a further argument the Court advanced its quite formalistic approach:

"Judging on the basis of these materials, the Court is unable to find that the "Scorpions" were, in mid-1995, de jure organs of the Respondent. Furthermore, the Court notes that in any event the act of an organ placed by a State at the disposal of another public authority shall not be considered an act of that State if the organ was acting on behalf of the public authority at whose disposal it had been placed." 72

It seems as if the Court condones a kind of "outsourcing" of genocide - if States pass the actual commission of the crime to "another public authority" including paraState entities, they bare no responsibility.

The question of responsibility for de facto organs of a State is not an easy one. In brief, the evidence has to show that the relationship of the perpetrators to the State "was so much one of dependence on the one side and control on the other that it would be right to equate" the perpetrators with a State organ or "as acting on behalf of that Government". Looking for such a relationship of dependence in the Srebrenica genocide the Court reached a negative conclusion. In its view, the "political, military and logistical relations between the federal authorities in Belgrade and the authorities in Pale, between the Yugoslav army and the VRS, had been strong and close in previous years..., and these ties undoubtedly remained powerful, they were, at least at the relevant time, not such that the Bosnian Serbs' political and military organizations should be equated with organs of the FRY". The same conclusion was reached with respect to the Scorpions. Here again, the Court took only the very narrow time frame in July 1995 looking meticulously for signs of discord between the allies. ${ }^{73}$

If the VRS or the "Scorpions" were not organs of the State of Serbia, could Serbia be responsible based on Art. 8 of the Draft Articles? It provides for the responsibility of the State "if the person or group of persons is in fact acting on the instructions of, or under the direction or control of that State in carrying out the conduct". The Court confirmed that this is the rule of international customary law. ${ }^{74}$

The question of the necessary "control" has been a source of controversy between the ICJ and the ICTY. The ICJ has established the necessary level of control in the Nicaragua case in 1986 when it opted for the strict or effective control test. ${ }^{75} \mathrm{On}$ the other hand, the ICTY opted for the "overall control" test. ${ }^{76}$ On this point the ICJ made clear its stance that the two courts have distinct jurisdictions and that the ICTY was not called to give views "on issues of general international law which do not lie

71 The "Scorpions" were established in 1991 as part of the Ministry of Interior of the remnants of the former Yugoslavia. During the Milošević trial in The Hague the film was presented showing them killing prisoners in Trnovo, Srebrenica.

72 Bosnia 2007, para. 389.

73 Bosnia 2007, para. 394.

74 ibid, para. 398 .

75 Military and Paramilitary Activities in and against Nicaragua (Nicaragua v. United States of America) (Merits, Judgment, I.C.J. Reports 1986, pp. 62-64).

76 Tadić case, Appeals Chamber (IT-94-1-A, Judgment, 15 July 1999). 
within the specific purview of its jurisdiction". ${ }^{77}$ In view of the ICJ, the "effective control" must be exercised or the State's instructions must be given "in respect of each operation in which the alleged violations occurred, not generally in respect of the overall actions taken by the persons or groups of persons having committed the violations". ${ }^{78}$ In the case of Srebrenica, the Court was not ready to accept that it was established that the massacres were committed on the instructions or under the direction of organs of Serbia. Neither did the Court accept that FRY exercised effective control over the operations in Srebrenica in July 1995. It was evident that the FRY assisted the VRS military, politically and logistically throughout the entire period before, during and after the genocide was committed. Nevertheless, Bosnia did not prove that Belgrade did that "in full awareness that the aid supplied would be used to commit genocide" so the FRY was neither responsible for complicity in genocide. ${ }^{79}$ The ICJ did, however, find Serbia responsible for the breach of the Convention with respect to the duty to prevent and punish the crime. ${ }^{80}$

\section{CONCLUSION}

The case on the breach of the Convention on Genocide before the ICJ presented the Court with the opportunity to clarify some of its aspects relating to the definition of the crime and the question of State responsibility.

The Court confirmed that States as well as individuals may commit genocide. Furthermore, it held that article IX of the Convention gives the Court jurisdiction to adjudicate charges by one State that another has perpetrated genocide ${ }^{81}$ Furthermore, the Court clarified the elements of the crime of genocide. In its interpretation the Court kept a conservative approach, keeping the term genocide as close to the context of Holocaust as possible. It demands that dolus specialis is clearly established and that it refers to the intent to destroy - biologically and physically - a defined and separate group. Despite many similarities the Court refused to equate ethnic cleansing with genocide because of the lack of the dolus specialis. It is thus clear that the ICJ holds that ethnic cleansing is to be treated as a separate crime. In other words, the term genocide is meant to convey "mass killing" whereas "ethnic cleansing" signifies

77 Bosnia 2007, para. 401. Abass criticises this approach: "It is thus clear that the ILC and the ICTY's positions reflect, to a greater extent than the ICJ, the state of customary international law on the modality of control to be proved in respect of an allegation of de facto organs of States". Abass, A., Proving State Responsibility for Genocide: The ICJ in Bosnia v. Serbia and the International Commission of Inquiry for Darfur, Fordham International Law Journal, 31, 4/2007, p. 896.

78 "Genocide will be considered as attributable to a State if and to the extent that the physical acts constitutive of genocide that have been committed by organs or persons other than the State's own agents were carried out, wholly or in part, on the instructions or directions of the State, or under its effective control." Bosnia 2007, para. 400-401.

79 ibid, para. 423.

80 ibid, para. 471. The judges were split on all points of the judgment. Vice-President AlKhasawneh appended a dissenting opinion and Judges Ranjeva, Shi and Koroma appended a joint dissenting opinion.

81 Schabas, W., op. cit., 2009, p. 491. 
the forced removal from a particular territory. Strictly using these elements the ICJ established that the crime of genocide had been committed only in Srebrenica refusing to accept the multitude of violent and horrific crimes elsewhere in Bosnia as being part of the same genocidal scheme..$^{82}$

With respect to the Serbia's responsibility for the Srebrenica genocide perpetrated by the Bosnian Serbs forces the Court rejected the claims that the VRS or the Scorpions acted as de jure or de facto organs of Serbia. Furthermore, it also refused to acknowledge that Serbia would be responsible based on the rule of international customary law as codified by Art. 8 of the Draft Articles on State Responsibility. It chose to disregard evidence pointing to the shared objectives of the Republika Srpska and the FRY and their common activities in achieving the ethnically cleansed Greater Serbia. Instead, it applied the Nicaragua control test despite the fact that the relationship between Serbia and the Republika Srpska were much closer and open than the clandestine relationship between the US government and the contras in Nicaragua. As the Vice-President of the Court, Judge Al-Khasawneh noted in his dissent: "When... the shared objective is the commission of international crimes, to require both control over the non-State actors and the specific operations in the context of which international crimes were committed is too high a threshold. The inherent danger in such an approach is that it gives States the opportunity to carry out criminal policies through non-state actors or surrogates without incurring direct responsibility therefore." ${ }^{83}$

The intention of the Court was to preserve the term genocide only for the "super-crime". One may wonder whether with this approach the Court actually made genocide a "perfect crime" that will be impossible to prove in inter-State cases? ${ }^{84}$

\section{BIBLIOGRAPHY}

Books:

1. Daillier, Patrick, Pellet, Alain, Quoc Dinh, Nguyen, Droit International Public, $7^{\text {th }}$ ed., Paris, L.G.D.J., 2002,

2. Lemkin, Raphael, Axis Rule in Occupied Europe: Laws of Occupation, Analysis of Government, Proposals for Redress, Washington: Carnegie Endowment for World Peace, 1944.

3. Lemkin, Raphael, Genocide, American Scholar, 15, 2/1946, 227- 230,

4. Schabas, William, Genocide in International Law: The Crime of Crimes, $2^{\text {nd }}$ ed., Cambridge, Cambridge University Press, 2009,

82 In his very strong dissenting opinion the vice-president Al-Kasawneh asks the Court: "The Court essentially ignores the facts and substitutes its own assessment of how the Bosnian Serbs could have hypothetically best achieved their macabre Strategic Goals. ... Coupled with population transfers, what other inference is there to draw from the overwhelming evidence of massive killings systematically targeting the Bosnian Muslims than genocidal intent?" Bosnia 2007, Dissenting Opinion of Judge Al-Khasawneh, para. 41.

83 ibid, para. 39.

84 In July 2019 the Dutch Supreme Court ruled that The Netherlands bear a "very limited liability" for the events in Srebrenica putting aside, nevertheless, the direct applicability of the Genocide Convention. Text of the judgment available at: Rechtspraak, <https://uitspraken.rechtspraak.nl/ inziendocument?id=ECLI:NL:HR:2019:1284> (visited 19.09.2019). 
5. Shaw, Malcolm, International Law, $6^{\text {th }}$ ed., Cambridge, Cambridbe University Press, 2008.

Articles:

1. Abass, Ademola, Proving State Responsibility for Genocide: The ICJ in Bosnia v. Serbia and the International Commission of Inquiry for Darfur, Fordham International Law Journal, 31, 4/2008, pp 871-910,

2. Blum, Rony et al., 'Ethnic Cleansing' Bleaches the Atrocities of Genocide, European Journal of Public Health, 18, 2/2007, pp 204-209,

3. Degan, Vladimir Đ., Zločin genocida pred Međunarodnim sudom u Haagu, Zbornik radova Pravnog fakulteta u Splitu, 53, 2/2016, pp 329-376,

4. Petrović, Dražen, Ethnic Cleansing - An Attempt at Methodology, European Journal of International Law, 5, 3/1994, pp 342-359,

5. Sa'Couto, Susana, Reflections on the Judgment of the International Court of Justice in Bosnia's Genocide Case against Serbia and Montenegro, Human Rights Brief, 15, 2/2007,

6. Singleterry, Douglas, "Ethnic Cleansing" and Genocidal Intent: A Failure of Judicial Interpretation?, Genocide Studies and Prevention: An International Journal, 5, 1/2010, pp 39-67. Available at: <http://scholarcommons.usf.edu/gsp/vol5/iss1/4> (visited 17.09.2019).

Case Law:

1. Application of the Convention on the Prevention and Punishment of the Crime of Genocide (Bosnia and Herzegovina v. Yugoslavia), Preliminary Objections, Judgment of 11 July 1996, I.C.J. Reports 1996, p. 595

2. Application of the Convention on the Prevention and Punishment of the Crime of Genocide (Bosnia and Herzegovina v. Serbia and Montenegro), Judgment, I.C.J. Reports 2007, p. 43,

3. Application of the Convention on the Prevention and Punishment of the Crime of Genocide (Croatia v. Serbia), Preliminary Objections, Judgment, I.C.J. Reports 2008, p. 412

4. Application of the Convention on the Prevention and Punishment of the Crime of Genocide (Croatia v. Serbia), Judgment, I.C.J. Reports 2015, p. 3,

5. Armed Activities on the Territory of the Congo (New Application: 2002) (Democratic Republic of the Congo v. Rwanda), Jurisdiction and Admissibility, Judgment, I.C.J. Reports 2006, p. 6,

6. Blagojević and Jokić, (IT-02-60-T), Judgment, 17 January 2005,

7. Jorgic v. Germany, ECtHR 2007,

8. Krstić case, Appeals Chamber (IT-98-33-A), Judgment of 19 April 2004,

9. Military and Paramilitary Activities in and against Nicaragua (Nicaragua v. United States of America) Merits, Judgment, I.C.J. Reports 1986,

10. Mothers of Srebrenica et. al., Hoge Raad, NL, ECLI:NL:HR:2019:1284, 19 July 2019.

11. Perinçek v. Switzerland, ECtHR GC 2015,

12. Prosecutor v. Kambanda, ICTR 97-23-S, Judgment and Sentence, 4 September 1988,

13. Reservations to the Convention on the Prevention and Punishment of the Crime of Genocide (Advisory Opinion), I.C.J. Reports 1951,

14. Tadić case, Appeals Chamber (IT-94-1-A, Judgment, 15 July 1999). 


\section{Vesna Crnić-Grotić*}

Sažetak

\section{ZLOČIN GENOCIDA PRED MEĐUNARODNIM SUDOM PRAVDE}

Kada je g. Raphael Lemkin oblikovao naziv genocida 1944. godine, zapravo je pokušavao ispuniti prazninu na postojećem popisu međunarodnih zločina, jer ni jedan, prema njegovu mišljenju, nije bio odgovarajući da opiše strašna masovna zlodjela tijekom Drugog svjetskog rata. Masovna pogubljenja Židova, Roma/ Cigana, Slavena i drugih skupina trebala su biti različita od „običnih“ zločina protiv čovječnosti. Njegova borba dovela je do prihvaćanja Konvencije UN o zabrani i kažnjavanju zločina genocida 1948. godine. Iako je primarna svrha Konvencija bila kažnjavanje pojedinaca, i države stranke mogu biti odgovorne zbog počinjenja zločina genocida. Odredba članka IX. Konvencije koja predviđa nadležnost Međunarodnog suda u Haagu jasno pokazuje u tom smjeru. Pa ipak, prva parnica pred tim sudom bila je ona između Bosne i Hercegovine protiv Srbije 1993. godine koju je Sud meritorno presudio 2007. Sljedeća presuda odnosila se na predmet Hrvatska protiv Srbije 2015. Ni jedna od konačnih presuda nije utvrdila odgovornost tužene države za zločin genocida iako je Sud utvrdio postojanje genocida u Bosni. Članak će prikazati koje zahtjeve Međunarodni sud smatra potrebni kako bi se utvrdio zločin genocida i koja je to karika potrebna između zločina i tužene države.

Ključne riječi: Konvencija o genocidu; Međunarodni sud; parnica o genocidu; Bosna i Hercegovina; Hrvatska; Srbija.

Zusammenfassung

\section{VÖLKERMORD VOR DEM INTERNATIONALEN GERICHTSHOF}

Als Raphael Lemkin 1944 den Begriff Völkermord erfand, versuchte er, die Lücke in der bestehenden Liste internationaler Verbrechen zu füllen, da seiner Ansicht nach kein dieser Verbrechen geeignet war, die schrecklichen Massengräueltaten des Zweiten Weltkriegs anzusprechen. Die Massenvernichtung von Juden, Zigeunern, Slawen und anderen Gruppen hätte sich von ,gewöhnlichen“ Verbrechen gegen die Menschlichkeit unterscheiden sollen. Sein Kampf führte 1948 zur Verabschiedung des Übereinkommens der Vereinten Nationen zur Verhütung und Bestrafung des

* Dr. sc. Vesna Crnić-Grotić, redovita profesorica u trajnom zvanju, Sveučilište u Rijeci, Pravni fakultet; vesnacg@pravri.hr. 
Völkermordes. Obwohl das Übereinkommen in erster Linie dazu bestimmt war, einzelne Täter zu bestrafen, können Vertragsstaaten auch für dasselbe Verbrechen zur Verantwortung gezogen werden. Der Verweis im Artikel IX des Übereinkommens auf die Zuständigkeit des Internationalen Gerichtshofs zeigt klar in diese Richtung. Die erste Rechtssache, die vor diesem Gericht anhängig wurde, war die Rechtssache Bosnien gegen Serbien im Jahr 1993, und der Gerichtshof entschied 2007 in der Sache. Die nächste Rechtssache betraf die Rechtssache Kroatien gegen Serbien im Jahr 2015. Keine der beiden endgültigen Entscheidungen stellte die Verantwortung des beklagten Staates für den Völkermord fest, obwohl das Verbrechen im Fall von Bosnien festgestellt worden war. Deshalb werden in diesem Beitrag die Voraussetzungen für den Völkermord und die fehlende Verbindung zwischen dem Verbrechen und dem beklagten Staat untersucht.

Schlüsselwörter: Genozid-Konvention; Internationaler Gerichtshof; GenozidProzess; Bosnien; Kroatien; Serbien.

\author{
Riassunto
}

\title{
IL CRIMINE DI GENOCIDIO DINNANZI ALLA CORTE INTERNAZIONALE DI GIUSTIZIA
}

Quando il sig. Raphael Lemkin nel 1944 forgiò il termine genocidio, in realtà tentò di colmare la lacuna esistente nell'elenco dei crimini internazionali, poiché nemmeno uno, a suo parere, corrispondeva alla descrizione dei terribili crimini di massa commessi durante la Seconda guerra mondiale. Lo sterminio di massa degli ebrei, della popolazione rom, degli slavi, come anche di altri gruppi dovevano essere differenti rispetto ai „comuni“ crimini contro l'umanità. La sua lotta condusse all'accoglimento della Convenzione ONU per la prevenzione e la repressione del crimine di genocidio del 1948. Benché lo scopo primario della Convenzione era quello di punire i singoli, anche gli stati contraenti possono essere responsabili per la commissione di crimini di genocidio. Le disposizioni dell'art. IX della Convenzione, il quale prevede la giurisdizione della Corte internazionale dell'Aia, danno un chiaro segnale in tale senso. Tuttavia, la prima controversia dinnanzi a tale Corte fu quella della Bosnia ed Erzegovina contro la Serbia del 1993 nella quale la Corte pervenne ad una decisione sul merito nel 2007. La sentenza successiva si riferì al caso della Croazia contro la Serbia del 2015. Nemmeno una delle sentenze definitive non ha accertato la responsabilità dello stato convenuto in giudizio con l'accusa per il crimine di genocidio benché la Corte abbia accertato l'esistenza del genocidio in Bosnia. Il contributo illustrerà quali requisiti la Corte internazionale reputi necessari al fine di accertare il crimine di genocidio e quale fu il nesso mancante tra il crimine e lo stato convenuto.

Parole chiave: Convenzione sul genocidio; Corte internazionale; processo sul genocidio; Bosnia ed Erzegovina; Croazia; Serbia. 
